Historia Slavorum Occidentis

2020, nr $3(26)$

ISSN 2084-1213

DOI: $10.15804 /$ hso200302

\author{
Aleksander Matecki (Poznań) \\ ORCID 0000-0002-9767-8154
}

\title{
O szesnastowiecznym wizerunku Bolesława Chrobrego autorstwa Tomasza Tretera i wczesnym wyglądzie grobowca tego władcy w poznańskiej katedrze
}

Słowa kluczowe: grobowiec Bolesława Chrobrego, Tomasz Treter, katedra poznańska, Złota Kaplica, średniowieczna rzeźba kamienna, grobowiec Henryka Pobożnego, cesarz Karol IV, Petr Perler

Keywords: Bolesław I the Brave's tomb, Tomasz Treter, the Poznań cathedral, the Golden Chapel, medieval stone sculptures, Henry II the Pious' tomb, emperor Charles IV, Petr Perler

Abstract: The article is dedicated to an attempt at reconstructing the early appearance of the
tomb of king Bolesław I the Brave in the Poznan cathedral, destroyed in 1790. By referring to
the discussion of the tomb's founder and the changes in its shape, the author has focused on
K. Stronczyński's theory from 1887 that the chalcography by A. Mylius (1595) consolidated
the early portrait of the king's statue. The scholar was of an opinion that king Bolesław's
sculpture was modelled by the tomb of duke Henry II the Pious. The original of the portrait
was created by Tomasz Treter, an artist born in Poznań who could have captured the state of
the king's statue around 1585 (a variant of the portrait was provided by S. Sarnicki in 1594).

Katastrofalny stan sklepień katedry poznańskiej w 1755 r. spowodował, że została ona zamknięta i poddana remontowi, a „starodawny” grobowiec króla Bolesława 
Wielkiego, zwanego Chrobrym, który od schyłku XIV w. zdobił środek jej prezbiterium, został zdemontowany ${ }^{1}$. Odnowiono go, lecz w 1772 r. (po pożarze) ponownie rozebrano, posąg króla zaś został poddany w latach 1783-1784 „rekonstrukcji” rzeźbiarskiej przez Augustyna Schöpsa ${ }^{2}$. W tym nowym kształcie nagrobek dotrwał tylko do 30 III 1790 r., gdy upadająca wieża spowodowała jego całkowitą destrukcję. Wkrótce potem Poznań i Wielkopolska znalazły się pod pruskim panowaniem, co udaremniło zamiar odbudowy królewskiego grobowca, z którego do dziś przetrwało tylko kilka mniej istotnych elementów. Znaczenie postaci króla Bolesława dla historii świeżo „rozebranej” Polski oraz dla lokalnej pamięci o dawnej stołeczności Poznania spowodowało, że starań o jego upamiętnienie nie zaniechano. Dlatego wygląd poznańskiej królewskiej tumby szybko stał się przedmiotem naukowej dysku$\mathrm{sji}^{3}$, toczonej później przede wszystkim w gronie historyków sztuki i mediewistów. Uczeni do dziś spierają się zarówno o pierwotny wygląd grobowca, znanego tylko z późnych przekazów ikonograficznych (wśród których najważniejsza jest tzw. rycina ks. Przyłuskiego), jak o datę i motywy jego powstania, a także o zakres dokonanych w czasach nowożytnych modyfikacji kształtu wieńczącej go kamiennej postaci króla ${ }^{4}$. Równolegle rozważany był problem ustalenia fundatora i przyświecających mu motywów i tu kluczowe znaczenie miała opinia Jana Długosza, przypisującego fundację grobowca królowi Kazimierzowi Wielkiemu ${ }^{5}$. Zwolennikiem tej tezy był

1 Jak pisał Józef Nowacki: „W toku tych prac około wszelkich sklepień i dachów w latach 1755-1757 i zapewne także następnych usunięto grobowiec królewski”. Por. tegoż, Groby królewskie w katedrze poznańskiej, Miesięcznik Kościelny Archidiecezji Poznańskiej 7 (1952), nr 7/8, s. 200.

2 W tej fazie miał on ksztalt „ponownie zmontowanego grobowca z nową plytą lub tylko nową rzeźbą króla, roboty Schöpsa”. Por. Z. Białłowicz-Krygierowa, Gotycki grobowiec Bolestawa Chrobrego $w$ katedrze poznańskiej. Weryfikacja podstaw rekonstrukcji, [w:] Studia z dziejów sztuki dedykowane Mieczystawowi Zlatowi, red. L. Kalinowski i in., Wroclaw 1998, s. 73.

3 Zdaniem Józefa Łukaszewicza grobowiec króla Bolesława „zajmuje dotąd głowy i pióra tylu znamienitych badaczy dziejów kraju naszego, od Czackiego i Lelewela począwszy, aż do Bielowskiego". Por. tegoż, Krótki opis historyczny kościołów parochialnych, kościótków, kaplic, klasztorów, szkótek parochialnych, szpitali i innych zakładów dobroczynnych $w$ dawnej Dyecezyi Poznańskiej, t. I, Poznań 1858, s. 15.

4 J. Kębłowski w 1986 r. uważal, że „teoretycznej rekonstrukcji dzieła” trzeba dokonać „na podstawie krytycznej analizy zachowanych fragmentów, źródeł pisanych (opis Patelskiego z ok. 1750 r.) oraz ikonograficznych (tzw. rycina Przyłuskiego), a także napisu”. Por. tegoż, Pomnik króla Bolestawa Chrobrego - nagrobek czy relikwiarz?, [w:] Symbolae historiae artium. Studia $z$ historii sztuki Lechowi Kalinowskiemu dedykowane, Warszawa 1986, s. 257.

5 Ryszard Gansiniec opisał genezę tego poglądu następująco: „Wiszniewski wygrzebał z rękopisu słowa Długosza o grobowcach poznańskich, z których wyczytał, że pierwotny Bolesław I 
Ryszard Gansiniec, który w dwóch obszernych, wydanych niemal równocześnie artykułach szczegółowo omówił zarówno różne aspekty powstania królewskiego grobowca i jego kształtu ${ }^{6}$, jak i treść towarzyszącego mu epitafium ${ }^{7}$. Dla mych rozważań ważniejszy jest tekst poświęcony historii tumby, gdzie Autor nie tylko przytoczył wszystkie źródła „pisane” (dał też tłumaczenia łacińskich tekstów), ale również omówil dostępne mu późne przekazy ikonograficzne (s. 142-149) oraz porównał je z wyobrażeniami postaci władców na nagrobkach śląskich (s. 149-154)8.

W kontekście Długoszowej informacji o fundacji Kazimierza Wielkiego przed kilku laty poznański grobowiec wszechstronnie omówili zarówno historyk sztuki Marek Walczak ${ }^{9}$, jak i mediewista Piotr Węcowski ${ }^{10}$. Problem ustalenia fundatora

grobowiec już zapadły Kazimierz Wielki w XIV wieku był podniósł i odnowił”. Por. tegoż, Grobowiec Bolesława Wielkiego, Archeologia 3 (1949) [druk: 1952], s. 123-168. A przecież od $1604 \mathrm{r}$. istniała wydana przez Tomasza Tretera (i uzupełniona przez niego) drukowana edycja tego katalogu: J. Długosz, Vitae Episcoporum Posnaniensium Per Ioannem [...] Dlugossium $[. .$.$] conscriptae [...] Opera Thomae Treteri [...] cum earundem supplemento in lucem editae,$ Brunsbergae [Braniewo] 1604.

6 R. Gansiniec, Grobowiec Bolestawa Wielkiego, Archeologia 3 (1949) [druk: 1952], s. 123-168. Ostatnią część tego tekstu Autor poświęcił próbie wykazania, że król Bolesław otoczony był w Poznaniu kultem religijnym i w związku z tym tumba miała charakter relikwiarza - por. cz. IV. „TUMBA-RELIKWIARZ BOLESŁAWA WIELKIEGO” (s. 154-166) i cz. V. „BEATUS BOLESLAUS CHABRUS" (s. 166-168).

7 R. Gansiniec, Nagrobek Bolestawa Wielkiego, Przegląd Zachodni 7/8 (1951), s. 359-537.

8 R. Gansiniec przeprowadził tu bardzo drobiazgową analizę wyglądu i wyposażenia postaci króla na nagrobku (s. 149-166), reprodukując też ilustracje (il. 10-11). Warto przy tym odnotować proponowaną przez niego bardzo wczesną datację grobowca (na lata 1320-1350) i wspomnieć postulowanego fundatora (bp Jana IV Łodzia). Por. tegoż, Grobowiec, s. 166.

9 Por. M. Walczak, Rzeźba architektoniczna w Matopolsce za czasów Kazimierza Wielkiego, Kraków 2006. Autor stwierdzil, że: „Z opinią Długosza zgadzają się też wspólnym głosem historycy sztuki” (s. 378), podkreślił też „zasługę Janusza Kębłowskiego”, który zanegował tezę Gansińca, co przeniosło rozważania dotyczące „tumby Chrobrego z dziedziny hagiografii na grunt rozważań czysto historycznych", s. 379.

10 Jego zdaniem „Kazimierz Wielki wpisywał się w ten sposób w tradycję pierwszych Piastów, legitymizując swą władzę i wskazując na dawne oraz obecne istnienie zjednoczonego Królestwa Polskiego". Por. P. Węcowski, Początki Polski w pamięci historycznej późnego średniowiecza, Kraków 2014, s. 170. Nieco wcześniej (s. 168) przywołał ryzykowne przypuszczenie, że jeśli Kazimierz Wielki był również „fundatorem figur Przemysła II i Ryksy w kaplicy Królewskiej”, to „można by je przyjąć za wzmocnienie tezy o »królewskich « konotacjach, jakie miał wywoływać nagrobek Bolesława Chrobrego. Kazimierz Wielki upamiętniałby i odwoływał się zarówno do pierwszego króla i twórcy królestwa (Bolesława Chrobrego), jak i do odnowiciela Królestwa Polskiego (Przemysła II)". 
był wszechstronnie dyskutowany ${ }^{11}$, poszerzyła go ostatnio Halina Manikowska, analizując praktyki upamiętniania przeszłości u schyłku średniowiecza ${ }^{12}$.Zwróciła ona uwagę na kwestię ciągłości tradycji pochówków monarszych w poznańskiej katedrze oraz na poszukiwania innych niż Długoszowe świadectw określających okoliczności i czas fundacji reprezentacyjnego grobowca ${ }^{13}$. Autorka zauważa, że „ustawienie pośrodku nawy tumby Bolesława Chrobrego i umieszczenie na niej nietypowo bogatego w treści historyczne epitafium zyskuje jednak nieco inne treści, gdy za sprawcę tej fundacji uznamy biskupa Jana Doliwę. Fundacja nowego nagrobka służyłaby wówczas przede wszystkim podniesieniu pozycji i prestiżu biskupa poznańskiego, [...], i jego katedry, która ani nie miała grobów świętych patronów królestwa i Polaków, jak krakowska i gnieźnieńska, ani nie była miejscem koronacji” ${ }^{14}$. Jednak Tomasz Jurek sądzi, że „nie należy raczej przypisywać Janowi fundacji nagrobka Bolesława Chrobrego w katedrze”, przypuszczając, iż Bolesławowi Chrobremu „nagrobek postawił wprawdzie Kazimierz Wielki, ale na pewno w porozumieniu z miejscowym biskupem [podkr. A.M.], w którego kręgu powstało być może wówczas wierszowane epitafium pierwszego króla, a stojący tuż obok ołtarz ufundował wojewoda Mikołaj z Dębna, krewny biskupa Jana Doliwy" ${ }^{15}$. Studia autorstwa M. Walczaka $(2006){ }^{16}$ i H. Manikowskiej $(2018){ }^{17}$ obejmują - dzięki kompetencjom autorów zarówno obszar badań historii sztuki, jak i mediewistyki, dzięki czemu mogę pominąć szczegóły dotychczasowych polemik nad okolicznościami wzniesienia królewskiej tumby w poznańskiej katedrze. Niemal niezależnie od tej dyskusji, choć w powiązaniu z próbą ustalenia chronologii erygowania monumentu, żywo roztrzą-

11 Pierwszą fazę naukowych sporów wokół poznańskiego królewskiego grobowca omówił R. Gansiniec w tekście: Grobowiec Bolestawa Wielkiego, Archeologia 3 (1949) [druk: 1952], s. $123-130$.

12 H. Manikowska (wspólpr. P. Okniński), Przeszłość osobista i tożsamość wspólnotowa. Formy i treści memorii w późnym średniowieczu, [w:] Przeszłość w kulturze średniowiecznej Polski, t. 2, red. H. Manikowska, Warszawa 2018, s. 271-331.

13 Por. A. Gąsiorowski, Tradycja poznańskich grobów monarszych, [w:] Kultura średniowieczna i staropolska. Studia ofiarowane Aleksandrowi Gieysztorowi w pięćdziesięciolecie pracy naukowej, Warszawa 1991, s. 231-239.

14 H. Manikowska (wspólpr. P. Okniński), Przeszłość osobista i tożsamość, s. 331.

15 Por. T. Jurek, Biskupstwo poznańskie w wiekach średnich, Poznań 2018, s. 312-313 oraz 471.

16 M. Walczak, Rzeźba architektoniczna w Małopolsce, s. 377-379, 383-385 oraz 412, gdzie podsumowuje: „Przejawem reprezentacji majestatu panującego była też z pewnością fundacja nagrobków ojca w Krakowie i protoplasty dynastii Piastów - Bolesława Chrobrego w Poznaniu". 17 Halina Manikowska (współpr. P. Okniński), Przeszłość osobista i tożsamość, s. 271-331. 
sano treść towarzyszącego królewskiemu pochówkowi epitafium (osią tej dyskusji stało się odtworzenie autentycznego tekstu i jego datowanie $)^{18}$. Z kolei zajmujący się królewskim nagrobkiem historycy sztuki skupiali się albo na analizie stylistycznej rzeźb ocalałych z rozbitej tumby (Marian Gumowski, Gwido Chmarzyński, Janusz Kębłowski) ${ }^{19}$, albo na prześledzeniu losów grobowca, jego remontów i rekonstrukcji. Szczególnie godne odnotowania są dwa teksty, powstałe prawie w tym samym czasie, a uzupełniające się wzajemnie, które dały pełen przegląd stanowisk oraz podsumowanie dyskusji ${ }^{20}$. Ich autorki - Zofia Białłowicz-Krygierowa i Zofia Ostrowska-Kębłowska - nie mogąc oprzeć się na starszej dokumentacji ikonograficznej, skupiły uwagę na czasach nowożytnych, analizując przebudowy (i odbudowy) tumby w XVIII w. W tym samym okresie zupełnie inaczej, bo od strony historycznych losów grobowca podszedł do tego problemu Szczęsny Skibiński, zestawiając główne dane na temat przypuszczalnych okoliczności i motywów erygowania królewskiej tumby ${ }^{21}$. Mimo długiej i wszechstronnej dyskusji autorytet Jana Długosza sprawił,

18 Żywe dyskusje, jakie wzbudzał powiązany z tym grobowcem epitafijny napis, pozostawię natomiast poza sferą niniejszych rozważań. Por. ustalenia B. Kürbis, Epitafium Bolesława Chrobrego. Analiza literacka i historyczna, Roczniki Historyczne 55-56 (1989-1990), s. 95-132 oraz podsumowujący ważny etap dyskusji na ten temat artykuł D. Zydorek, $W$ sprawie tradycji o pochówku Bolesława Chrobrego - raz jeszcze, [w: ] Scriptura Custos Memoriae. Prace historyczne, red. D. Zydorek, Poznań 2001, s. 511-522. Nowe światło na wczesny kształt tego tekstu rzucił Edward Skibiński, który wykorzystując nowe źródła - szczególnie datowany na początek XV w. kodeks z Huntington (przechowywany w The Huntington Library, San Marino California) - ustalił nowe brzmienie epitafium. Por. tegoż, Epitafium Bolesława Chrobrego, Studia Epigraficzne 2 (2006), s. 73-77, oraz Epitafium Bolesława Chrobrego. Wydanie i analiza, Studia Epigraficzne 5 (2013), s. 43-56. W tym drugim artykule na s. 55 jest czytelna reprodukcja sfotografowanej w ultrafiolecie tej nieznanej kopii epitafium.

19 Kanon takiego podejścia wyznaczył M. Gumowski, Sarkofag grobowy Bolesława Chrobrego $w$ katedrze poznańskiej, Muzeum Wielkopolskie 2 (1926), s. 83-97. Do poglądów pozostałych tu wymienionych badaczy odniosę się w różnych miejscach dalszej części tekstu.

20 Por. Z. Białłowicz-Krygierowa, Gotycki grobowiec Bolesława, s. 71-85, oraz osobny rozdział zatytułowany: I. Średniowieczny nagrobek Bolesława Chrobrego w wieku XVIII. Przemiany i zniszczenie. Tradycja i legenda, w większej pracy Zofii Ostrowskiej-Kębłowskiej, Dzieje Kaplicy Królów Polskich czyli Złotej w katedrze poznańskiej, Poznań 1997, s. 13-25.

21 Por. S. Skibiński, Nagrobek Bolesława Chrobrego w katedrze poznańskiej, Kronika Miasta Poznania 1995, z. 2, s. 165-176. Niestety, jest to tekst pozbawiony przypisów - warte jednak odnotowania są dwie opinie tego uczonego, że: „nad miejscem pogrzebania Przemysła ustawiony został nagrobek Bolesława Chrobrego” (s. 168) oraz iż: „Postać króla na płycie wierzchniej kontynuuje stereotypowe ujęcie znanej z nagrobków śląskich figury książęcej z przydanymi akcesoriami królewskimi” (s. 176). 
iż zarówno historycy sztuki, jak i badacze historii dynastycznej, szukając źródeł ideowych i rzeźbiarskich inspiracji dla budowy poznańskiego grobowca, pozostają zwolennikami tradycyjnego poglądu wiążącego fundację z osobą króla Kazimierza ${ }^{22}$, tym samym ograniczając czas budowy do okresu przed rokiem 1370.

Ponieważ monumentalna tumba pierwszego króla Polski została u schyłku XVIII w. całkowicie zniszczona, rekonstruowanie wyglądu zabytku, który dziś fizycznie nie istnieje, jest bez wątpienia zadaniem karkołomnym. Zapewne $\mathrm{z}$ tego powodu Zofia Białłowicz-Krygierowa zdecydowała się na ograniczenie swych bardzo wnikliwych dociekań do analizy kształtu grobowca po przebudowach XVII i XVIII w. ${ }^{23}$ A przecież istnieją przesłanki do podjęcia dyskusji nad wcześniejszym wyglądem królewskiego posągu na poznańskiej tumbie - już w 1887 r. Kazimierz Stronczyński postawił hipotezę, że przedstawiająca króla Bolesława grafika Arnolda Myliusa ( $w$ wydanym w $1594 \mathrm{r}$. jego dziele Principum et Regum Polonorum Imagines ad vivum expressae), mogła być wzorowana na portretowej części pierwotnego („gotyckiego”) posągu władcy wieńczącego poznański grobowiec ${ }^{24}$. Nie przypisując sobie zasług pioniera, zamierzam jedynie przypomnieć (i nieco uzupełnić) zgromadzone przez niego argumenty. Choć przed i po K. Stronczyńskim tajemnice królewskiego grobowca zainteresowały wielu poważnych uczonych ${ }^{25}$, przeprowadzona przez niego krytyczna analiza osiemnastowiecznych źródeł ikonograficznych tak ściśle splotła się $\mathrm{z}$ argumentami wywodzonymi z „rozbioru” grafiki A. Myliusa, że nowatorski pomysł został podchwycony jedynie przez badaczy dokonań Tomasza Tretera - jednego z ważniejszych twórców szesnastowiecznej grafiki, którego cykl miedziorytów stał się „źródłem” Myliusowych Imagines ${ }^{26}$. Nawet Zofia Ostrowska-Kębłowska, która

22 Szczególnie wyraźnie widać oddziaływanie tego poglądu na stanowisko M. Walczaka - por. tegoż, Rzeźba architektoniczna w Małopolsce, Kraków 2006.

23 Wbrew obiecującemu tytułowi nie zajęła się „gotyckim” okresem historii tumby. Por. Z. Białlowicz-Krygierowa, Gotycki grobowiec Bolestawa, s. 71-85.

24 Por. K. Stronczyński, Dawny grobowiec Bolesława Chrobrego w Poznaniu, Biblioteka Warszawska 3 (1887), s. 165-177, 407-420 oraz nadbitka o osobnej paginacji. Cytuję ten tekst podając zarówno stronę w tomie Biblioteki Warszawskiej, jak i w nadbitce.

25 Wedle słów Mariana Sokołowskiego, recenzującego studium K. Stronczyńskiego, poznańskim pomnikiem „zajmowali się Lelewel, Bentkowski, Karol Hofman, a przede wszystkiem [217] Łukaszewicz, a napisem na nim położonym, Michał Wiszniewski, Dominik Szulc i szczególnie Bielowski w tomie I. monumentów”. Por. M. Sokołowski, rec. z: K. Stronczyński, Dawny grobowiec Bolesława Chrobrego w Poznaniu, Kwartalnik Historyczny 2 (1888), s. 213-220.

26 Najpierw, w 1980 r. B. Stawiarska (Źródła ikonograficzne pocztu wtadców polskich Tomasza Tretera, [w:] Sprawozdania PTPN. Wydział Nauk o Sztuce 98 (1980), s. 63-67), nieco później 
wspomina w przypisie o T. Treterze ${ }^{27}$, w tekście zasadniczym nie wiąże dopełnienia przez Stronczyńskiego interpretacji osiemnastowiecznych rycin ze szczegółami „wyczytanymi” z miedziorytu A. Myliusa: „Zdaniem Stronczyńskiego, który bodaj ostatni miał w ręce rycinę [ks. Przyłuskiego], płaszcz był zapięty »na klamrę z orłem «"28. Ponieważ w dyskusji o grobowcu króla Bolesława Chrobrego „problemy interpretacyjne dotyczą głównie insygniów władzy i ich porządku”29, a więc atrybutów częściowo zobrazowanych na rycinie T. Tretera, zdecydowałem się na podjęcie rozpatrzenia tego właśnie wątku. Zamierzam przy tym sięgnąć także po miedzioryty jego renesansowych naśladowców, na których - jak sądzę - uchwycono pewne ważne szczegóły wczesnego wyglądu postaci króla na płycie wierzchniej jego nagrobka.

Dotychczasowe próby rekonstrukcje plastycznego kształtu tumby pierwszego polskiego króla wykorzystywały przekazy ikonograficzne, ukazujące jej wygląd po remontach i modyfikacjach w ostatnim okresie istnienia (tzn. w XVII i XVIII w. $)^{30}$ w badaniach brano pod uwagę głównie tzw. rycinę Przyłuskiego oraz podobiznę miniaturowego drewnianego „relikwiarzyka” z Krakowa ${ }^{31}$. Dodatkowo Stanisław Zakrzewski wprowadził do obiegu naukowego w $1925 \mathrm{r}^{32}$ zmodyfikowany wariant „tzw. ryciny Przyłuskiego"33. Nie dziwi więc, że to właśnie te osiemnastowieczne

w szerszym kontekście - T. Chrzanowski, Działalność artystyczna Tomasza Tretera, Warszawa 1984.

27 „Klamra z orłem pojawiła się również u Tretera, który w swoim przedstawieniu Chrobrego miał się wzorować [podkr. A.M.] na nagrobku, por. Stawiarska s. 65”. Por. Z. Ostrowska-Kębłowska, Dzieje Kaplicy Królów, s. 16.

28 Tamże.

29 Z. Białlowicz-Krygierowa, Gotycki grobowiec Bolesława, s. 85.

30 Przykładem gruntownego studium opartego na tych późnych przekazach jest wspomniany wyżej tekst Z. Białłowicz-Krygierowej pt: Gotycki grobowiec Bolesława, s. 71-85. Tam też umieszczono pełną dokumentację ikonograficzną do rozpoznania przemian nowożytnego kształtu średniowiecznego nagrobka.

31 Obie podobizny królewskiego nagrobka wprowadził w 1887 r. do naukowego obiegu K. Stronczyński, ich wnikliwą zaś analizę formalną i historiograficzną przeprowadziła Z. Białłowicz-Krygierowa dopiero w sto dziesięć lat później.

32 Por. S. Zakrzewski, Bolestaw Chrobry Wielki, Lwów-Warszawa-Kraków 1925, po s. 534; rysunek jest opisany jako: „Ryc. 34a. Dawny nagrobek Chrobrego w katedrze poznańskiej, zniszczony $w$ XVIII w. Wedtug rysunku $w$ Muzeum xx. Lubomirskich we Lwowie. Widoczny napis jest t. $z w$. Epitafjum".

$33 \mathrm{Wg}$ Z. Białłowicz jest to: „połączenie ryciny Przyłuskiego z przedstawieniem króla w zbroi plytowej: napierśniku, nabiodrkach i naręczakach według schematu jak w relikwiarzyku krakowskim i na akwareli M. Stachowicza”. Por. tejże, Gotycki grobowiec Bolesława, s. 82. 
podobizny nagrobka posłużyły za jedyny wzorzec wyglądu postaci króla na upamiętniającej jego poznańską „średniowieczną” tumbę brązowej tablicy umieszczonej na ścianie katedry w $2002 \mathrm{r}^{34}$
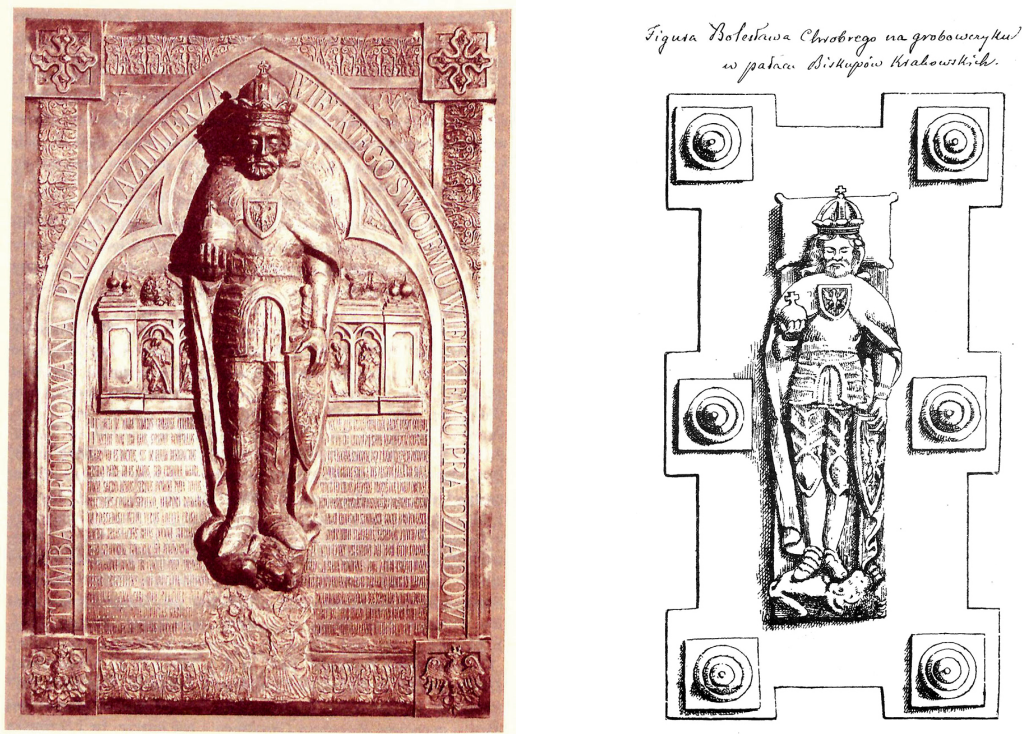

Il. 1 i 2. Tablica z 2002 r. w zestawieniu z podobizną królewskiej postaci na tzw. „relikwiarzyku” z Krakowa (na którym prawa ręka króla jest uniesiona wyżej)

Jak wyżej wspomniałem, w 1887 r. K. Stronczyński poddał wnikliwej analizie opublikowaną w 1594 r. rycinę A. Myliusa, którą uznał za świadectwo pierwotnego wyglądu postaci króla Bolesława na jego poznańskim grobowcu. Gdy w 1955 r. Maria Ochońska odnalazła w zbiorach Ossolineum wykonany przez Tomasza Tretera poczet władców Polski („Regum Poloniae Icones” z 1591 r.), okazało się, że zestaw rycin Myliusa (w tym podobizna Bolesława) jest nieco tylko zmodyfikowaną wersją zawartych tam królewskich wizerunków ${ }^{35}$. Trop ten w 1980 r. wykorzystała Barbara

\footnotetext{
34 Por. I. Błaszczyk, Wyraz ideowy i artystyczny nagrobków Bolesława Chrobrego w Katedrze Poznańskiej, [w: Średniowieczna inskrypcja i tumba Bolesława Chrobrego w Katedrze Poznańskiej, Poznań 2002, s. 10-24; ten sam tekst w: Wyraz ideowy i artystyczny nagrobków Bolesława Chrobrego w Katedrze Poznańskiej, http: //www.katedra.archpoznan.pl/wp-content/uploads/2015/07/ dok6.pdf [dostęp 11 XI 2018].

35 Por. M. Ochońska, Zabytek szesnastowiecznego rytownictwa „Regum Poloniae Icones” Tomasza Tretera $w$ zbiorach Ossolineum, Ze Skarbca Kultury (1955), z. 1 (7), s. 273-289.
} 
Stawiarska badająca dokumentacyjny aspekt twórczości T. Tretera, która jednak, przywołując hipotezę Stronczyńskiego, nie sięgnęła bezpośrednio do jego artykułu i zawartej w nim szczegółowej analizy portretu króla Bolesława ${ }^{36}$. Zasadnicza część pracy magisterskiej B. Stawiarskiej została opublikowana, lecz w druku pozbawiono ją szesnastowiecznej ikonografii - kluczowej dla klarowności przeprowadzonego wywodu. Dlatego nie dziwi, że konkluzje tej wersji pracy nie zainteresowały zbyt wielu badaczy ${ }^{37}$. Kilka lat później Tadeusz Chrzanowski poświęcił twórczości T. Tretera obszerne studium, w którym znalazło się także wnikliwe omówienie pracy B. Stawiarskiej ${ }^{38}$. Poznański grobowiec królewski jako inspiracja analizowanej ryciny Tretera nie był jednak dla niego na tyle ważny, by zająć się nim bardziej szczegółowo. Lecz drogi badawcze autorów interesujących się twórczością T. Tretera z jednej a poznańską tumbą Bolesława Chrobrego z drugiej, skrzyżowały się jedynie na chwilę, kiedy Z. Ostrowska-Kębłowska odwołała się do jego twórczości, dopuszczając możliwość, że prowadząc prace przy „rekonstrukcji” postaci króla w połowie XVIII w. wzorowano się na tym portrecie ${ }^{39}$. Warto przy tym podkreślić, że wśród materiału ilustracyjnego znalazły się w jej książce trzy królewskie podobizny z Icones Tretera - oprócz Bolesława są to Mieszko i Władysław Łokietek (wedle dzisiejszej wiedzy

36 Por. B. Stawiarska, Źródła ikonograficzne pocztów władców polskich wywodzacych sięz „Regum Poloniae Icones” Tomasza Tretera, Praca magisterska napisana pod kier. doc. A. Karłowskiej-Kamzowej w Inst. Hist. Sztuki UAM w Poznaniu, Poznań 1980. W tej kwestii autorka nie wyszła poza ustalenia K. Stronczyńskiego (cytowane zresztą pośrednio: „za R. Gansińcem, Grobowiec Bolestawa Chrobrego (Archeologia III, 1949, str. 123)”, skąd zaczerpnęła całość swoich wniosków. Por. s. 22, przyp. 7.

37 B. Stawiarska, Źródła ikonograficzne pocztu władców polskich Tomasza Tretera, Sprawozdania PTPN. Wydział Nauk o Sztuce 98 (1980), s. 63-67. W wersji drukowanej większość tekstu zaczerpnięto z rozdz. II pracy magisterskiej zatytułowanego „Geneza ikonografii”.

38 T. Chrzanowski tezy tej pracy co do źródeł Regum Poloniae Icones omawia na s. 164-171, a ich przypuszczalne powiązania z wydanymi w „zwierciadlanym odbiciu” rycinami Myliusa na s. 171-172 swej pracy Działalność artystyczna Tomasza Tretera. Nie poprawiła tej sytuacji praca magisterska Anny Szulczewskiej analizująca ikonograficzne przekazy postaci króla Bolesława Chrobrego (Ikonografia Bolesława Chrobrego od schytku X do końca XVIII wieku, Inst. Historii Sztuki UAM. Poznań 2007. Promotor: Szczęsny Skibiński), bowiem autorka wspomniała tu tylko zdawkowo o rycinach Tretera i Myliusa.

39 Przypuszczała, że „korzystano również z Tretera, u którego płaszcz króla spięty jest niemal identyczną małą tarczą z orłem”. Por. Z. Ostrowska-Kębłowska, Dzieje Kaplicy Królów, s. 23. Jest to raczej wątpliwe, bo egzemplarze Icones były rzadkością, a B. Stawiarska pokazała, że to Myliusowe „»Imagines« a nie poczet Tretera był bezpośrednim źródłem inspiracji” dla różnych naśladowców. Por. tejże, Źródła ikonograficzne pocztów, s. 39. 
podstawą dla tego wizerunku była rzeźba przedstawiająca Kazimierza Wielkiego) ${ }^{40}$. Brak szerszej recepcji hipotezy o inspirowaniu się autorów renesansowych portretów króla Bolesława Chrobrego jego posągiem na poznańskiej tumbie ${ }^{41}$ - poza lakoniczną wzmianką w ważnej monografii Teresy Jakimowicz ${ }^{42}$ - poświadcza stwierdzenie J. Kębłowskiego, że ponieważ analizowane przez badaczy osiemnastowieczne „przekazy ikonograficzne ukazują przedmioty nowożytne" [podkr. A.M.], nie znamy wczesnego kształtu „korony oraz innych regaliów”43.

Chcąc poszerzyć wykorzystywany przez badaczy poznańskiego grobowca króla Bolesława wąski krąg źródeł ikonograficznych, przeanalizuję wskazówki zawarte w rycinie Tomasza Tretera - Poznańczyka z Chwaliszewa - przypominając przy okazji jego zasługi dla staropolskiej „historiografii obrazowej” pionierski cykl literackich królewskich „portretów” pióra innego Wielkopolanina Janicjusza ${ }^{45}$. Ponieważ jestem świadom podążania jedynie śladami K. Stronczyńskiego i B. Stawiarskiej, postawiłem sobie „minimalistyczne” zadanie, aby przez pryzmat wywodzących się od ryciny Tretera szesnastowiecznych podobizn króla Bolesława spojrzeć zarówno na kształt królewskiej korony, jak i „innych regaliów”: królewskiej zapinki płaszcza (z Orłem w koronie), dzierżonego w prawej dłoni jabłka lub domniemanego miecza (czy może berła albo włóczni „bojownika Chrystusa”).

40 Por. Z. Ostrowska-Kębłowska, Dzieje Kaplicy Królów, il. 14-16, po s. 64.

41 Przez K. Stronczyńskiego wiązanym z grafiką A. Myliusa, przez B. Stawiarską i T. Chrzanowskiego zaś z podobizną króla Bolesława w Icones T. Tretera.

42 Informuje ona tylko: „Sięgnął Treter [...] do postaci Chrobrego na nagrobku w katedrze poznańskiej”, powołując się w przypisie m.in. na drukowaną wersję pracy B. Stawiarskiej. Por. Teresa Jakimowicz, Temat historyczny $w$ sztuce epoki ostatnich Jagiellonów, Warszawa -Poznań 1985, s. 85 .

43 J. Kębłowski, Pomnik króla Bolesława, s. 257-265.

44 Jego cykl rycin portretowych nawiązywał do wzorców wcześniejszych. O powstałym ok. 1508 r. z inicjatywy bpa Jana Lubrańskiego poczcie królów polskich w poznańskim pałacu biskupim ciekawą relację Jana Kochanowskiego przypomniał P. Węcowski: „W Poznaniu jest sala wielka biskupia, tam [...] byli namalowani rzędem wszyscy królowie Polscy, jakoż podobno jeszcze i dziś są”. P. Węcowski, Początki Polski, s. 172, przyp. 29.

45 Ok. 1541 r. Janicjusz ukończył cykl wierszowanych biografii władców Polski (oparty na faktografii zaczerpniętej z Kroniki Miechowity), zatytułowany w druku Vitae regum Polonorum elegiaco carmine descriptae. Ukazał się on dopiero w 1563 r. (Antwerpia) i przedrukowany został w 1565 i 1569 r. w Krakowie. Por. A. Małecki, Historyków nie zaniechaj czytać..., s. 234-235. 


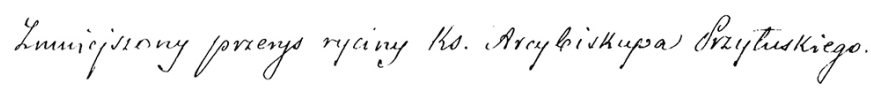

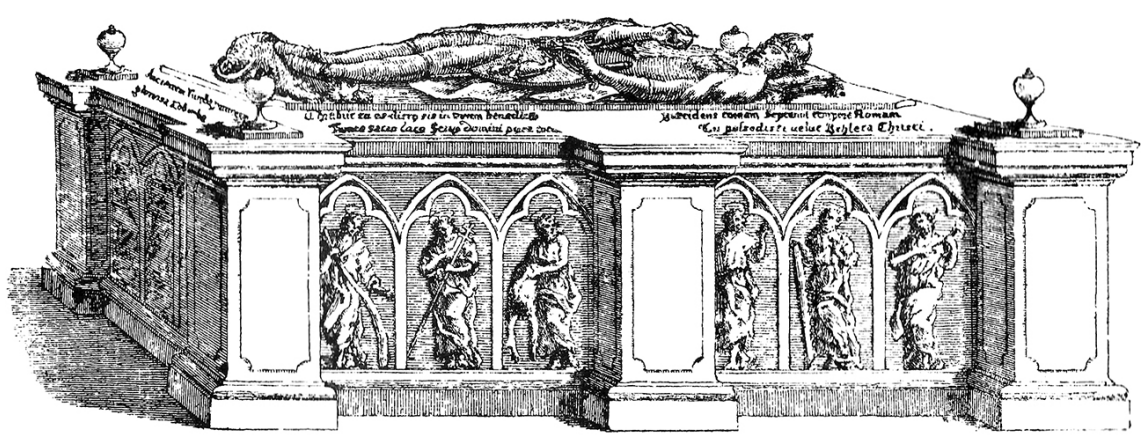

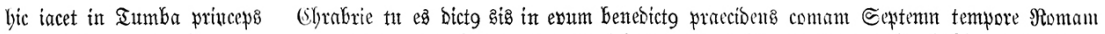

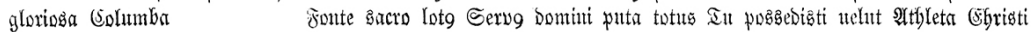

Il. 3. Tzw. rycina ks. Przyłuskiego wg edycji K. Stronczyńskiego z 1887 r. (z dopiskiem na nadbitce)

K. Stronczyński, publikując w 1887 r. po raz pierwszy podobizny tzw. ryciny ks. Przyłuskiego i przerysu górnej płyty krakowskiego „relikwiarzyka”, nie zamieścił reprodukcji tak szczegółowo analizowanej w swym artykule grafiki A. Myliusa, przez co niefortunnie pozbawił swą hipotezę najdobitniejszych, bo wizualnych argumentów. Może dlatego badający dzieje królewskiego grobowca historycy sztuki zlekceważyli jego nowatorski pomys ${ }^{46}$. Zapewne $\mathrm{z}$ tego powodu Z. Białłowicz-Krygierowa, która przecież chwali K. Stronczyńskiego za trafną interpretację ryciny Przyłuskiego, powątpiewa w odczytane przez tego autora widniejące na niej wyobrażenie Orła na tarczowej zapince płaszcza króla („na której - według Stronczyńskiego - Orzeł”77). A przecież takie odczytanie tej plakiety staje się oczywiste jedynie w świetle odwo-

46 Z. Białłowicz-Krygierowa uważała, że „oparta na autopsji obiektu rycina ks. Przyłuskiego”, datowana przez nią „nie później niż na lata 1744-1755”, to „najstarszy i zarazem najlepszy artystycznie przekaz"; por. tejże, Gotycki grobowiec Bolesława, s. 84.

47 Tamże, s. 74. Gdy autorka ta odnosi się do innego spostrzeżenia Stronczyńskiego, kładącego nacisk na „modernizację” królewskiej korony („słusznie umieścił ją w XVII w.”), zdradza niechcący zaniechanie skonfrontowania swej oceny z podstawą jego hipotezy, czyli z ryciną Myliusa: „Korona ta zastąpiła pierwotną, niewątpliwie otwartą, o izolowanych, narażonych na odlamanie kwiatonach [podkr. A.M.]. Można przypuszczać, że stało się to po pożarze katedry w 1622 r.”, tamże, s. 76. Na renesansową podobiznę zapinki z orłem zwróciła za to uwagę cytowana wyżej przeze mnie (przyp. 30) Z. Ostrowska-Kębłowska. 
łania się do wszechstronnie zinterpretowanej przez K. Stronczyńskiego ryciny A. Myliusa $^{48}$.

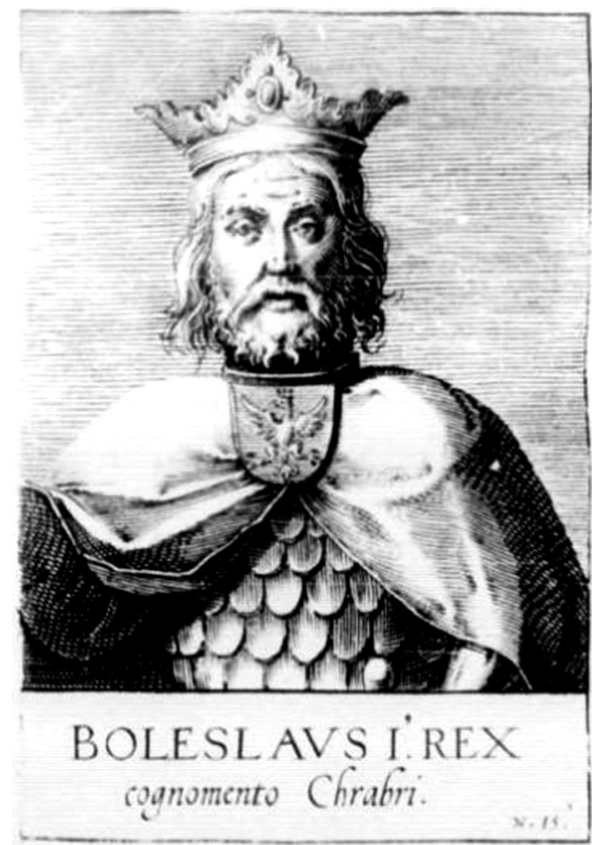

Il. 4. Postać króla Bolesława na miedziorycie z dzieła A. Myliusa (1594 r.)

Sprawa korony nie wymaga długiego komentarza: na rycinach Tretera i Myliusa król Bolesław ma „koronę u góry otwartą, XIV-u wiekowi i wcześniejszym właściwą"49, o rozchylonych fleuronach (przez co jest ona najbardziej chyba podobna do korony na wykonanych przez tych autorów przedstawieniach Władysława Łokietka) - nie mają one jednak kształtu lilii (zdobiących dawną tzw. Koronę Bolesława Chrobrego, czyli koronę koronacyjną królów polskich), lecz bliżej im do liści akantu. Za to kwestia królewskiego jabłka wymaga dużo więcej uwagi. K. Stronczyński, komentując rycinę ks. Przyłuskiego w odniesieniu do królewskiego jabłka w prawej ręce króla, zauważa, że „ręka ta nadmiernie w górę wzniesiona a układ palców nie właściwy do trzymania tego znaku dostojności monarszej”ㅇ․ Zastrzeżenia wobec da-

\footnotetext{
48 Por. K. Stronczyński, Dawny grobowiec, s. 411/17.

49 Tamże.

50 Por. tamże, s. 409/15.
} 
lekiego od naturalności ułożenia królewskiej ręki mogłyby jego zdaniem dać się wytłumaczyć, gdyby umieszczony był w niej inny atrybut monarszej władzy, spotykany czasem na posągach średniowiecznych. Ponieważ na rycinie w zbiorze A. Myliusa prawe ramię króla Bolesława jest wyraźnie uniesione, odnosząc ten szczegół do stanu pierwotnego nagrobnego posągu, uczony dodaje: „wówczas figura Chrobrego na pomniku miała w prawem ręku nie jabłko królewskie, ale raczej włócznią"51. Komentując w dhugim przypisie wygląd szesnastowiecznego miedziorytu, K. Stronczyński postawił tezę, że wizerunki Myliusa „o ile możności rysowane były podług spółczesnych pomników" oraz - jako pierwszy badacz - przeprowadza pionierskie porównanie kilku postaci władców z ich ewentualnymi nagrobkowymi pierwowzorami. Porównuje również niektóre ważne szczegóły z układem postaci króla na rycinie Przyłuskiego. Badacz ten zasugerował następnie, iż rycina przedstawiająca Bolesława Chrobrego ma „układ całości taki, jak [w] grobowcu Henryka pobożnego w Wrocławiu", co w świetle dzisiejszej wiedzy o inspiracjach twórców poznańskiej rzeźby gotyckiej płynących ze Śląska (a nawet z Czech) ${ }^{52}$ sprawia, że do tego spostrzeżenia odwołam się w dalszej części mego wywodu.

Ponieważ trudności z określeniem fundatora tumby są w naturalny sposób powiązane z precyzyjnym datowaniem fundacji, kwestia sprecyzowania wzorców, na których się oparto (i czasu ich powstania) może mieć rozstrzygające znaczenie dla chronologii problemu. H. Manikowska wskazuje na tę kwestię w cytowanych wyżej uwagach na temat dopuszczenia innego niż król Kazimierz fundatora poznańskiego grobowca - w wypadku inicjatywy kościelnej przesuwając jego powstanie na koniec XIV w. ${ }^{53}$ Chciałbym się do tej tezy odnieść nieco szerzej. Nie ulega bowiem wątpliwości, że bogaty program religijny - nietypowy w kontekście monarszych pochówków - zmusza do powtórzenia pytania postawionego w tytule artykułu J. Kębłowskiego: „nagrobek czy relikwiarz”54. To pozwala z większą dozą prawdopodobieństwa szukać wzorców dla poznańskiej królewskiej tumby i wieńczącego jej program posągu Bolesława Chrobrego w kręgu rzeźbiarskich przedstawień zasłużo-

51 Por. tamże, przyp. na s. $411 / 17$.

52 Por. A. Soćko, Znaczenie Śląska dla rozwoju rzeźby gotyckiej $w$ Wielkopolsce od połowy XIII do początku XVI wieku, [w:] Procesy przemian w sztuce średniowiecznej. Przełom - regres - innowacja - tradycja. Studia z historii sztuki, red. R. Kaczmarek, R. Eysymontt, Warszawa 2014, s. 163-176.

53 Por. wyżej s. 165.

54 Autor ten pisze: „W naszej części Europy jest to raczej wyjątkowy typ przedstawień [...] w kręgu nagrobków tumbowych”. Por. J. Kębłowski, Pomnik króla Bolesława, s. 262. 
nych dla Kościoła monarchów. Sądząc po otaczających jego postać figurach apostolów i proroków oraz naprowadzającej na cel wzniesienia królewskiej tumby scenie koronacji Maryi przez Chrystusa, pierwszy polski królewski pomazaniec powinien być postrzegany jako „athleta Christi”. Królewski grobowiec w Poznaniu ma charakter wzniesionej po wielu latach od śmierci władcy memorii. Najbliższym odpowiednikiem - chronologicznie i geograficznie - takiego upamiętnienia zasłużonego dla krzewienia czy też obrony wiary władcy jest bez wątpienia czternastowieczny grobowiec Henryka Pobożnego we Wrocławiu ${ }^{55}$, inspiracji zaś dla ukształtowania jego nagrobnego posągu znawcy przedmiotu szukają w Pradze, w posągu św. Wacława. W tym kontekście trzeba postawić retoryczne pytanie: czy datowana dziś na okres przed 1370 r. królewska tumba w katedrze poznańskiej mogła być wcześniejsza niż wzniesiony ok. 1381 r. nagrobek ks. Henryka we Wrocławiu? ${ }^{56}$

Jako ostatnią - lecz nie najmniej ważną - okoliczność chciałbym przypomnieć rozpoczętą przez cesarza Karola IV w 1373 r. w katedrze praskiej akcję wznoszenia nowych grobowców dla zmarłych w XII w. książąt czeskich, w której wykonaniu brał udział sam Piotr Parlér. Tak odległe w czasie od momentu zgonu osób upamiętnianych fundowanie im nowych figuralnych „memorii” raczej nie wypływało $\mathrm{z}$ inspiracji religijnych, ale miało na celu wyłącznie symboliczne zaznaczenie dawności i ciągłości władzy na praskim tronie ${ }^{57}$. Natomiast wedle opinii P. Skubiszewskiego „nagrobek Henryka II zaliczono do parlerowskiego kręgu rzeźby na Śląsku (Burgemeister i Grundmann, Probst, Pieńkowska, Chmarzyński)"58. Warto tu też przywołać inną opinię tego autora: „Bezpośrednim wzorem i impulsem dla powstania nagrobka Henryka II były tumby Przemyślidów ufundowane przez Karola IV w katedrze praskiej. [...] Fundacja ta wyraźnie służyła celom polityki dynastycznej.

55 Por. P. Skubiszewski, Nagrobek Henryka II we Wroctawiu i problem śląskiej rzeźby nagrobkowej $w$ drugiej połowie XIV wieku, Nadb. z: Prace Komisji Historii Sztuki 2 (1960), gdzie bardzo ważny rozdział III pt. Zagadnienie fundacji (s. 88-95) autor rozpoczyna od pytania: „Co spowodowało fundację nagrobka Henryka Pobożnego w okresie oddalonym niemal o półtora wieku od momentu śmierci księcia?".

56 Por. J. Kębłowski, Pomniki Piastów śląskich w dobie Średniowiecza, Wrocław 1971 (grobowiec ks. Henryka autor analizuje na s. 156-167, gdzie stwierdza, że „nagrobek Henryka Pobożnego powstał [...] w latach 1383-1385") oraz poświęcona temu nagrobkowi praca magisterska P. Skubiszewskiego, opublikowana jako wspomniany wyżej: Nagrobek Henryka II, s. 79-116.

57 J. Kuthan, J. Royt, Katedrála sv. Vita, Václava a Vojtěcha. Svatyně českych patronů a králů, Praha 2011; rozdział: Náhrobky českych knižat a králù v chórových kaplích katedrály, s. 196$-202$.

58 Por. P. Skubiszewski, Nagrobek Henryka II, s. 88. 
Analogiczne były motywy wzniesienia nagrobka Henryka II i to właśnie mocno wiąże wrocławski zabytek z jego praskimi pierwowzorami” ${ }^{59}$. Czy jednak król Kazimierz Wielki był w podobnej sytuacji i musiał legitymizować w Poznaniu swe prawa do krakowskiego tronu? Przeciw takiej koncepcji źródeł fundacji poznańskiego nagrobka królewskiego wypowiedział się przed wielu laty Antoni Gąsiorowski, który postawił pytanie, „czemu miało służyć erygowanie przez króla w niechętnej mu Wielkopolsce grobowca, który przypominał o świetności tej dzielnicy. [...] O wiele bardziej zrozumiałe byłoby wzniesienie sarkofagu z inicjatywy środowisk wielkopolskich w okresie rywalizacji wielkopolsko-małopolskiej, po śmierci króla lub tuż przed nią, w okresie spisania testamentu dla Kaźka wołogojskiego. Byłby wówczas ów grobowiec symbolem wielkiej państwowej tradycji Wielkopolski”o0.

W tym miejscu zamierzam wrócić do zasadniczego pytania, postawionego już przez K. Stronczyńskiego: czy odwzorowana przez T. Tretera wzniesiona prawa ręka króla Bolesława była - wzorem posągu ks. Henryka Pobożnego (dodajmy tu też praską statuę św. Wacława), który w prawej ręce dzierży włócznię - wyposażona w ten atrybut? Starałem się pokazać, że akceptowana przez znawców twórczości T. Tretera hipoteza, iż jego portret Bolesława Chrobrego może za swą podstawę mieć posąg króla z jego poznańskiego grobowca, zlekceważona została przez badaczy na równi z interesującą sugestią K. Stronczyńskiego o wzorcowej roli tumby Henryka Pobożnego. Idąc za postulatem Z. Białłowicz-Krygierowej, wzywającej do podjęcia próby poszerzenia znajomości „bazy źródłowej”, zacznę od analizy prawdopodobieństwa utrwalenia wyglądu poznańskiego grobowca króla Bolesława na rycinach powstałych w ostatnim ćwierćwieczu XVI w. Poważnym mankamentem hipotezy K. Stronczyńskiego było, że przywołany przez niego jako świadek wczesnego kształtu królewskiego grobowca, A. Mylius, nie miał żadnych związków z Poznaniem. Inaczej rzecz miała się z autorem ryciny z Icones, służącej A. Myliusowi za wzorzec ${ }^{61}$.

\section{Tamże, s. 95.}

60 A. Gąsiorowski, Tradycja poznańskich grobów monarszych, s. 237.

61 Dobitnie ten fakt zależności akcentuje T. Chrzanowski, gdy stwierdza, że A. Mylius „wkrótce już miał wykorzystać poczet Tretera we własnym wydawnictwie. Można przypuszczać, że dysponował jakimiś materiałami naszego artysty, że korzystał z nich wedle własnego uznania [...] nie troszcząc się o prawa autorskie". Por. T. Chrzanowski, Działalność artystyczna Tomasza Tretera, s. 159. Nieco zaś dalej stwierdza on, iż konsekwencją wydania przez Myliusa dzieła Kromera było, „że wszystkie podobizny królów i książąt wykonane przez Tretera dostały się do rąk Niderlandczyka, a ten - skoro z takich czy innych przyczyn nie przyozdobily one dzieł Kromera - wykorzystał je na własną rękę, zlecając ich rytowanie i dopisując do nich (głównie na podstawie pracy Kromera) krótkie życiorysy”. Por. tamże, s. 172. 
Tomasz Treter przyszedł bowiem na świat niemal „na progu” poznańskiej katedry, w leżącym pomiędzy odnogami Warty kościelnym Chwaliszewie ${ }^{62}$. Mial przy tym rozległe kompetencje, by się królewskim grobowcem zainteresować - zdaniem Henryka Barycza dał się poznać jako filolog, historyk, poeta, teolog, pisarz ascetyczny, rysownik i sztycharz ${ }^{63}$. W jego bogatym dorobku zamierzam wyróżnić krótki okres twórczego życia po śmierci kard. Stanisława Hozjusza, gdy po przyjeździe w październiku 1584 r. do Krakowa Treter próbował swych sił na niwie „historii wizualnej" ${ }^{\prime \prime}$. Jak uważa Tadeusz Chrzanowski, ważną rolę odegrała tu próba wykorzystania przygotowanych wówczas ilustracji w czwartej edycji De origine et rebus gestis Polonorum Marcina Kromera. Mimo fiaska tego projektu, warto pamiętać, że nieco później w Rzymie przygotował powiązany z tą działalnością plakat „Reges Poloniae” - czyli tzw. „Orzeł Tretera”, opublikowany w $1588 \mathrm{r}^{65}$, uwieńczeniem zaś tej pracy stał się wydany w $1591 \mathrm{r}$. album Regum Poloniae icones ${ }^{66}$.

T. Treter w okresie prób nawiązania współpracy z M. Kromerem przebywał w Polsce od połowy października 1584 do 23 III 1586 r. ${ }^{67}$ Sporą część tego czasu spędził w Krakowie i Niepołomicach (skąd wyjeżdżał, „aby malować Kraków”) ${ }^{68}$. Lech Kajzer odnotował, że rozbudzone w Rzymie własne zainteresowania historyczne realizował, sporządzając podobizny polskich władców w oparciu m.in. o ich

62 T. Treter ur. 1 III 1547 - zm. 11 II 1610 w Lidzbarku, był synem introligatora Jakuba i Agnieszki z Różanowskich. Por. hasło Tomasz Treter, [w:] Wielkopolski Stownik Biograficzny, Warszawa-Poznań 1981, s. 772; znamienne, że był on wówczas na tyle zapomniany, iż biogram nie jest podpisany, a redakcja daje odsyłacz do Nowego Korbuta, t. 3; Hist. nauki.

63 H. Barycz, Polacy na studiach w Rzymie w epoce Odrodzenia 1440-1600, Kraków 1938, s. 151.

64 Por. wspomnianą wyżej wnikliwą pracę T. Chrzanowskiego: Działalność artystyczna Tomasza Tretera, której piąty rozdzial, zatytułowany „Historyzm i propaganda patriotyczna” (s. 151-190), poświęcony jest w dużej mierze tej kwestii - szczególnie s. 159-170.

65 T. Chrzanowski zakłada, że ikonografia wizerunków królewskich w „Orle” jest „pochodną pocztu osobnych miedziorytów, który [...] istniat już niewątpliwie wcześniej w [...] cyklu rysunków, które Treter zawoził Kromerowi."; por. tamże, s. 163.

${ }^{66}$ Cykl reprodukowany był kilkukrotnie, m.in. w Szwecji w końcu XVII w. Por. K. Mroziewicz, Regum Poloniae Icones Tomasza Tretera ze zbiorów Biblioteki Królewskiej w Sztokholmie i szwedzkie wątki w losach serii, Folia Historiae Artium, Seria Nowa 15 (2017), s. 25-34.

67 T. Chrzanowski, Działalność artystyczna Tomasza Tretera, s. 17; lecz jeszcze w końcu września 1584 r. był on w drodze. Por. Stanislai Rescii Diarium 1585-1589, Kraków 1915, s. 69.

68 Por. Stanislai Rescii Diarium 1585-1589, Kraków 1915, s. 82. 
wawelskie nagrobki ${ }^{69}$. Z Krakowa Treter wyjechał na Warmię i dotarł do Lidzbarka na początku czerwca 1585 r. ${ }^{70}$ Ponieważ planował odwiedzić swych rodziców, do Krakowa wracał przez Poznań, gdzie dotarł 15 lipca $^{71}$. W Poznaniu mimo panującej zarazy (trwała ona od połowy tego roku aż do początków roku następnego) ${ }^{72}$, przebywał do 11 października, kiedy wraz z ojcem wyruszył do Miechowa ${ }^{73}$. Ten kilkumiesięczny pobyt T. Tretera w Poznaniu - zapewne w domu rodziców na „przykatedralnym” Chwaliszewie - w okresie, gdy opracowywał on „króle niektóre wymalowane", wydaje się niezwykle istotny dla poruszanego tu tematu. To właśnie w tym czasie miał najlepszą sposobność, by odwzorować - tak jak zrobił to z „królami” na Wawelu - ówczesny wygląd stojącego „na środku katedry” średniowiecznego nagrobka Bolesława Chrobrego. Poczet portretów władców musiał być już mocno zaawansowany, skoro przed ponownym wyjazdem z Krakowa na Warmię ${ }^{74}$ rozważano ozdobienie rycinami przygotowywanej wówczas następnej edycji De origine (która ukazała się dopiero w 1589 r. $)^{75}$. Zaproponował to warmińskiemu biskupowi T. Płaza w liście wysłanym 3 II 1586 r.: „Będziesz WMC miał gościa wdzięcznego [...], $\mathrm{X}$. Tomasza ... Chce też D. Treterus napisać elogium WMCi Elspergae, które cum effigie Rmae D. Vrae damy przyłożyć do historyi. Ma też króle niektóre wymalowane, które WMCi ukaże, i chce je dać do historyi wyrzezać”76.

Starałem się tu zestawić informacje źródłowe pozwalające uznać, że T. Treter miał zarówno powody, jak i możliwości, by zainteresować się bliżej grobowcem króla

69 L. Kajzer, Średniowieczne źródła pomystów ikonograficznych Tomasza Tretera, Komunikaty Mazursko-Warmińskie 4 (118) 1972, s. 507-514.

70 Por. Stanislai Rescii Diarium 1585-1589, s. 99-102.

71 Pod datą 15 VII 1585 Reszka zanotowal: „D. Thomas Treter Posnaniam parentes videndi gratia profectus est. Dedi illi Przestrogam ad imprimendum et epistulam ad Lascum, dedi etiam mutuos talaros 40 ex his, quos mihi solvit D. Ioannes Hosius", s. 105.

72 Por. Kronika poznańskich pisarzy miejskich, oprac. J. Wiesiołowski, wstęp A. Warschauer, Poznań 2004, s. 68-69; zmarło wówczas „ponad tysiąc osób”. Por. Kronika Jezuitów poznańskich (młodsza), t. I: 1570-1653, oprac. L. Grzebień SJ, J. Wiesiołowski, Poznań 2004, s. 79-81.

73 Stanislai Rescii Diarium 1585-1589, s. 112.

74 Por. T. Chrzanowski, Działalność artystyczna Tomasza Tretera, s. 18.

75 Na temat innych okoliczności mogących być przyczyną niepowodzenia tych planów por. A. Małecki, „Historyków nie zaniechaj czytać...” Studia nad twórczością historyczną Marcina Kromera i jej renesansowa recepcją, Poznań 2013, s. 240-244.

76 List ten opublikował T. Chrzanowski przy swym artykule: Uzupetnienia do biografii Tomasza Tretera, Rocznik Historii Sztuki 15 (1985), s. 129-162; wersja elektroniczna: http://ebuw. uw.edu.pl/dlibra/ doccontent?id=22975\& from=FBC [dostęp 19 IV 2020]. 
Bolesława w poznańskiej katedrze - myślę, że można na tej podstawie uprawdopodobnić tezę, że posąg z katedralnej tumby stał się podstawą portretu tego władcy zamieszczonego w Icones. Podstawowe informacje źródłowe o królewskim średniowiecznym grobowcu w ujęciu chronologicznym zestawił kompetentnie Józef Nowacki ${ }^{77}$, zainteresowanych odsyłam więc do tego studium. Skupić się bowiem zamierzam na przypomnieniu przekazów ikonograficznych, które można powiązać z wyobrażeniem postaci Chrobrego na poznańskiej tumbie. Już przy pobieżnym porównaniu zauważymy, że pochodzące z końca XVI w. królewskie portrety opublikowane przez A. Myliusa i S. Sarnickiego wywodzą się z ryciny stworzonej przez Poznaniaka z Chwaliszewa. Powielają one najbardziej znamienny i najtrwalszy jej element - herbowego orła w koronie umieszczonego na zapince płaszcza ( $w$ formie tarczy) na królewskiej piersi. To ten właśnie atrybut ma dla mego wywodu kluczowe znaczenie, łączy bowiem wspomniane ryciny z wyobrażeniami późniejszymi, pochodzącymi z XVIII w., czyli ryciną ks. Przyłuskiego i „relikwiarzykiem” z Krakowa.
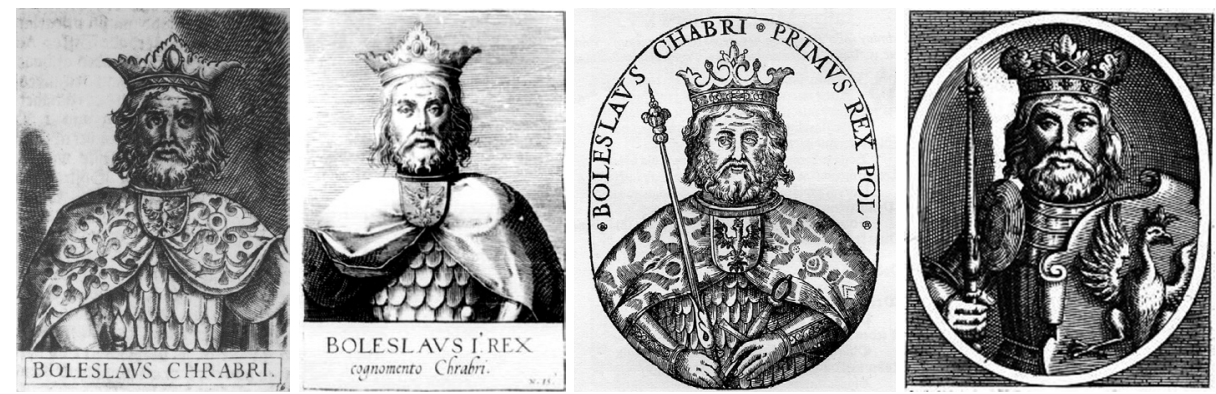

Il. 5, 6, 7 i 8. Ryciny T. Tretera (1591), A. Myliusa (1594), S. Sarnickiego (1594) i S. Neugebauera $(1644)$

Kompetentnej analizy cech charakterystycznych królewskiego posągu według zachowanych późnych ilustracji dokonała Z. Białłowicz-Krygierowa ${ }^{78}$ - to dzięki jej wnikliwości mogę swój wywód rozpocząć od opisu stanu późniejszego, zamierzając wypunktować tylko te elementy, które występują już na rycinie autorstwa T. Tretera. Mam nadzieję, że pozwoli to pokazać - mimo poświadczonych źródłowo zniszczeń i rekonstrukcji - ciągłość tradycji odtwarzania najważniejszych elementów postaci

77 Por. J. Nowacki, Groby królewskie w katedrze poznańskiej, Miesięcznik Kościelny Archidiecezji Poznańskiej 7 (1952), nr 7/8, s. 188-206.

78 Wszechstronnych analiz tych późnych przedstawień królewskiej postaci dokonała Z. Białłowicz-Krygierowa. 
króla. Jak wspominałem, najbardziej charakterystycznym elementem posągu, który uwieczniły wszystkie przekazy ikonograficzne, była tarczowa zapinka płaszcza z orłem. Wydaje się, że podobnie dobrze udokumentowany jest miecz przy lewym boku króla - jest on widoczny w postaci głowicy rękojeści na rycinie $\mathrm{T}$. Tretera oraz $\mathrm{w}$ „całości” zarówno na rycinie ks. Przyłuskiego, jak i „relikwiarzyku”. Natomiast tak ważna dla całości wymowy wizerunku króla tarcza herbowa przy pasie jest widoczna jedynie na przekazach z XVIII w. ${ }^{79}$ Brak jest też wczesnego poświadczenia przedmiotu dzierżonego w prawej ręce króla - późne przekazy pokazują królewskie jabłko. Wspomniałem wyżej, że K. Stronczyński na podstawie „nienaturalnego” ułożenia prawej ręki na królewskim posągu na rycinie Przyłuskiego uznal, iż „prezentowane” w wyciągniętych palcach prawej dłoni monarsze jabłko jest zamiennikiem zniszczonego wcześniej atrybutu. Aby pokazać, jak dalece mógł być uszkodzony posąg króla Bolesława na jego poznańskim grobowcu przypomnę zakres prac konserwatorskich i rekonstrukcyjnych, przeprowadzonych w połowie XIX w. przy zniszczonym posągu Henryka Pobożnego, kiedy figurze księcia „usunięto drewnianą prawą rękę, nową z wypalonej gliny wykonał rzeźbiarz Maechtig. Sporządzono nową blaszaną kopię i takiż miecz" ${ }^{\text {" }}$. Zaskakującą podatność kamiennej rzeźby na uszkodzenia uzmysławia dzisiejszy stan posągów władców Czech w ich nekropolii w praskiej katedrze ${ }^{81}$. Nie ulega natomiast wątpliwości, że efektem takich poważnych napraw i rekonstrukcji była utrwalona w obu późnych przekazach korona zamknięta „z białego kamienia” (wg słów ks. S. Patelskiego).

Przystępując do szczegółowego porównania ryciny T. Tretera z późniejszymi przekazami, warto najpierw odwołać się do sformułowań, jakich użył K. Stronczyński w stosunku do podobizny króla Bolesława w ujęciu A. Myliusa: „portret Bolesława Chrobrego, zdjęty widocznie z grobowca, ma prawą rękę w górę tak jak do trzymania włóczni wzniesioną, a koronę u góry otwartą". W obszernym przypisie uzupełnia ten opis porównaniem z ryciną Przyłuskiego: „widzimy na nim tę

79 Wg Z. Białłowicz-Krygierowej rycinie ks. Przyłuskiego widoczna jest „(zawieszona na mie$\mathrm{czu}$ ?) trójkątna tarcza $\mathrm{z}$ herbem Królestwa Polskiego, Orłem Białym o złożonych skrzydłach, bez korony, z insygniami królewskimi: w łapie prawej jabłko, w lewej domyślnie berło lub miecz”. Por. tejże, Gotycki grobowiec Bolestawa, s. 74.

80 Por. P. Skubiszewski, Nagrobek Henryka II, s. 80. Istnieje stara fotografia ukazująca posąg księcia zupełnie pozbawiony prawego ramienia.

81 Por. J. Kuthan, J. Royt, Katedrála sv. Vita, Václava a Vojtěcha. Svatyně českych patronů a králü, Praha 2011, s. 196-202. Większość rzeźb jest poważnie okaleczona przez brak dłoni (czasem całych ramion) a nawet głów (wyrzeźbiona w latach 1370-1380 postać Brzetysława II pozbawiona jest głowy, prawego ramienia oraz tarczy przy lewym boku), nie mówiąc o drobniejszych detalach. 
samą krótką, nieco rozdwojoną brodę, te samą kolczę czyli łuszczatą zbroję, a co najważniejsza tak samo płaszcz klamrą z wyobrażonym orłem zapięty. Korona tam jest nizka u góry otwarta" ${ }^{\prime 2}$. Na portrecie sporządzonym przez Tretera pierwszą cechą odróżniającą oba wizerunki jest fakt, że podobizna króla w katalogu T. Tretera jest wydrukowana w zwierciadlanym odbiciu w stosunku do portretu Myliusa. Że to odwrócenie odnosi się również do wyglądu pierwowzoru, wnioskować możemy przede wszystkim z pozycji herbowego Orła na zapince płaszcza, który wbrew zasadom heraldyki ma głowę zwróconą w lewo. Zwrócił już zresztą na to odwrócenie uwagę Chrzanowski ${ }^{83}$. Przez to odwrócenie nie prawa, lecz lewa ręka króla Bolesława - dzięki kształtowi fałd płaszcza - sprawia wrażenie wzniesionej ku górze. Gdy odwracając rycinę, skorygujemy tę wadę, ujawniają się inne drobne różnice: król na portrecie Tretera ma oczy zwrócone w prawo (w wersji Myliusa „patrzy” na widza), a korona na jego głowie ma wyraźnie wyróżnioną ozdobną dolną część.
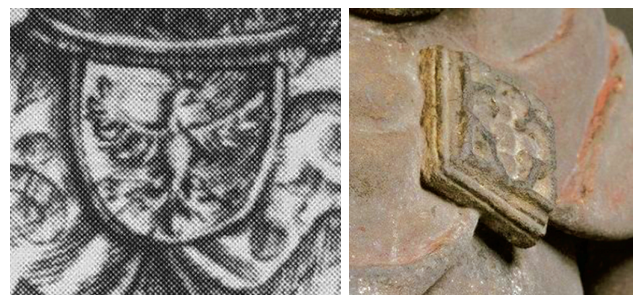

Il. 9 i 10. Powiększone zapinki płaszcza o kształcie herbowej tarczy z ryc. Tretera i Myliusa (obok zapinka Henryka Pobożnego)

Ważnym uzupełnieniem renesansowego kontekstu wyglądu i stanu królewskiego nagrobka może być rola odegrana przez dzieła Stanisława Sarnickiego, który sprawił, że informacja o poznańskiej tumbie znalazła się w szerszym obiegu czytelniczym ${ }^{84}$. Najpierw w wydanej w $1587 \mathrm{r}$. swej kronice opisał zły stan grobowca, podając nawet początek okalającego postać króla napisu: „Sepultus est Boleslaus in Basilica Posnaniensi in medio templi, cuius sepulchro Epitaphium est inscriptum, paruum quidem,

82 K. Stronczyński, Dawny grobowiec, s. 411/17.
83 Jego zdaniem miedzioryty z kopii Myliusa „są wiernym powtórzeniem wzorów Tretera, aczkolwiek w zwierciadlanym odbiciu [podkr. A.M.], a także w wykonaniu innego (i trzeba przyznać - sprawniejszego technicznie) rytownika niż nasz rzymski kanonik”. Por. T. Chrzanowski, Działalność artystyczna Tomasza Tretera, s. 172.

84 Nie poinformował o nagrobku króla ani skracający dzieło Długosza Miechowita, ani autor monumentalnej historii Polski - M. Kromer. 
sed ob reuerentiam antiquitatis valde iucundum. HAC IACET IN TVMBA REX PIVS GLORIOSA COLVMBA BOLESLAVS CHOBRI. [!] Literae sunt vetustate pene consumptae sicut \& ipsum sepulchrum, vtcunque tamen possunt legi." ${ }^{85}$. Sarnicki miał dość bliskie związki z Poznaniem: „był nie tylko w młodych latach w Poznaniu, lecz wrócił tam i w dojrzałym wieku" ${ }^{86}$, czego namacalnym dowodem jest odwołanie się do opowiedzianej mu przez „obywateli Poznania” ${ }^{87}$ anegdoty o pobycie króla Jagiełły w stolicy Wielkopolski, gdzie przytoczył jego polską wypowiedź: „Służ Bogu a dyabła nie gnieway”. Przypominam o tym, bowiem wydane w 1594 r. dzieło Statuta y Metrika przywileiow Koronnych ozdobił S. Sarnicki nawiązującym do ryciny Tretera portretem Bolesława Chrobrego, w którym zawarte zostały atrybuty symbolizujące ideę i rolę króla w ustroju państwa ${ }^{88}$. Przy porównaniu układu obu rycin dwa elementy pokazują, że S. Sarnicki w 1594 r. (a za nim Głuchowski, który w 1605 r., informując, że Bolesław: „dostał sobie, Sceptrum, miecza, korony, iak baczysz na głowie”, wyraźnie nawiązuje do zamieszczonego obok zaczerpniętego ze Statutów Sarnickiego portretu ${ }^{89}$ ) raczej opublikował rycinę przetworzoną

85 S. Sarnicki, Annales, sive de origine et rebus gestis Polonorum et Lituanorum, libri octo, b.m. 1587, L. VI, p. 226. Warte zwrócenia uwagi jest brzmienie tu przydomka królewskiego: „Chobri”, podczas gdy na rycinie w Statutach opublikowanych w 1594 r. widnieje wersja starsza - „Chabri”. Edward Skibiński sądzi, że „autor świadomie przekształcił pierwszy wiersz zgodnie ze swą wiedzą historyczną, zamieniając princepsa na króla". Por. tegoż, Epitafium Bolestawa Chrobrego, Studia Epigraficzne 5 (2013), s. 47. Na temat przydomku króla Bolesława por.: A. Małecki, Historyków nie zaniechaj czytać..., s. 251-255.

86 R. Gansiniec, Grobowiec Bolestawa Chrobrego, Archeologia 3 (1949), s. 134. Z Wielkopolską związał się w młodości, gdy „pierwsze nauki pobierał wraz z synami Andrzeja Górki (Łukaszem i Andrzejem) u Jana Koźmińczyka ok. roku 1542”. Por. Wojciech Sławiński, Stanistaw Sarnicki jako działacz reformacyjny (część I), Czasy Nowożytne, (2005), t. XVIII-XIX, s. 73. Upamiętnił te związki opisem podpoznańskiego Kórnika (należącego do Górków) w dziele Descriptio Veteris Et Novae Poloniae Cum Divisione Eiusdem Veteri Et Nova, [Kraków] 1585, p. D. Przekazana tu informacja o Poznaniu zawiera wyprowadzenie nazwy miasta od spotkania ces. Ottona z Bolesławem Chrobrym: „in loco primum notitiam christianae religionis (quod poznaniem prawdy vocant)", p. $\mathrm{E}_{4}$.

87 S. Sarnicki, Annales, „Referunt autem ciues Posnanienses”, L. VII, p. 343.

88 S. Sarnicki, Statuta y Metrika przywileiow Koronnych, jezzykiem polskim spisane, w Krakowie 1594, p. 3 (Aji); por. też J.A. Chrościcki, Sztuka i polityka. Funkcje propagandowe sztuki w epoce Wazów 1587-1668, Warszawa 1983, s. 30-31. Autorem rycin do tego dzieła był Jorg Bruckner - por. s. 61 , przyp. 31. Chrościcki informuje o tym, że „Księgę pierwszą rozpoczyna przedstawienie Bolesława Chrobrego (il. 27)".

89 J. Gluchowski, Ikones książą i królów polskich, Reprodukcja fototypiczna wydania z 1605 r., Wroclaw 1979, p. 39. 
przez rytownika w oparciu o wzorzec T. Tretera (z 1591 r.), niż naśladującą kopię opublikowaną przez A. Myliusa (w 1594 r.) - są to: wzorzystość płaszcza króla oraz ostrołukowy kształt łusek jego pancerza ${ }^{90}$.

Z konieczności moje amatorskie uwagi dotyczące ewentualnych podobieństw (czy możliwych związków) kształtu Treterowskiego portretu Bolesława z rzeźbionymi postaciami władców na nagrobkach śląskich i czeskich chciałbym ograniczyć do dwu charakterystycznych szczególów. Pierwszy to pojedyncza zapinka płaszcza $\mathrm{z}$ herbowym orłem - odmienna od wyobrażeń na nagrobku Kazimierza Wielkiego (gdzie płaszcz podtrzymuje łańcuch między dwoma zapinkami) - analogiczna natomiast do swego odpowiednika na posągu Henryka Pobożnego ${ }^{91}$. Spostrzeżenie K. Stronczyńskiego, że kształt płaszcza wokół prawej ręki na rycinie Myliusa (czyli „lustrzanym" odbiciu ryciny Tretera) wskazuje na jej uniesienie ku górze, zadziwiająco korespondując z tym właśnie pomnikiem - książę śląski ma także uniesione prawe przedramię, ponieważ dzierży w niej włócznię. Jeśli odwołać się do wzorcowego dla tej rzeźby przykładu praskiej postaci św. Wacława (obie postacie mają po lewej stronie przy pasie herbowe tarcze, a w prawej ręce dzierżą włócznie), to domysł taki wydaje się dopuszczalny. Choć Treter nie przedstawił dolnej części figury króla Bolesława, można jednak na podstawie opuszczonej lewej ręki i widniejącej u lewego boku rękojeści miecza wnioskować, że mogła tu znajdować się (uwidoczniona na późniejszej rycinie ks. Przyłuskiego przedstawiającej całość nagrobka) - analogicznie, jak w przypadku posągów ks. Henryka i św. Wacława - tarcza z Orłem.

Domysł dotyczący włóczni w prawej ręce króla zdaje się wspierać wspomniana już rycina przedstawiająca Bolesława jako „uosobienie” monarchii, zamieszczona w dziele S. Sarnickiego Statuta i Metryka Koronna z 1594 r. Chrobry dzierży tu w (opuszczonej?) prawej ręce berło, a lewą ręką podtrzymuje widoczną w całości rękojeść miecza (ułożenie ręki jest jednak inne niż na rycinie Tretera). Berło umieszczone w prawej królewskiej dłoni może wskazywać na to, że w tym okresie posągowi króla brak już było umieszczonego w niej pierwotnie atrybutu (wg Stronczyńskie-

90 Mam świadomość, że nietypowy dla epoki i nie odnotowany na innych zabytkach z tego okresu łuskowy pancerz na portrecie króla Bolesława stanowi interesujący problem, wart osobnego omówienia. Może tak właśnie T. Treter zinterpretował resztki polichromii pokrywające lentner (wzorzysty?) albo kolczugę na posągu króla? Nie czuję się na siłach, by się tu z tym zagadnieniem zmierzyć.

91 Szczegółowe omówienie kwestii zapinki przedstawił przed laty R. Gansiniec (nazywając ją „sprzączką” i „ryngrafem”), lecz trudno zgodzić się z jego konkluzją: „ryngraf jest tu zgoła nie na miejscu, tu może być tylko szeroka taśma spinająca płaszcz”. Por. tegoż, Grobowiec Bolesława Chrobrego, s. 163-164. 
go - włóczni). Nie można bowiem wykluczyć, że postępująca destrukcja najbardziej narażonych na uszkodzenie elementów w drugiej połowie XVI w. „zredukowała” pierwotną włócznię w prawej dłoni do fragmentu kojarzonego przez współczesnych już jedynie z berłem lub mieczem ${ }^{92}$.
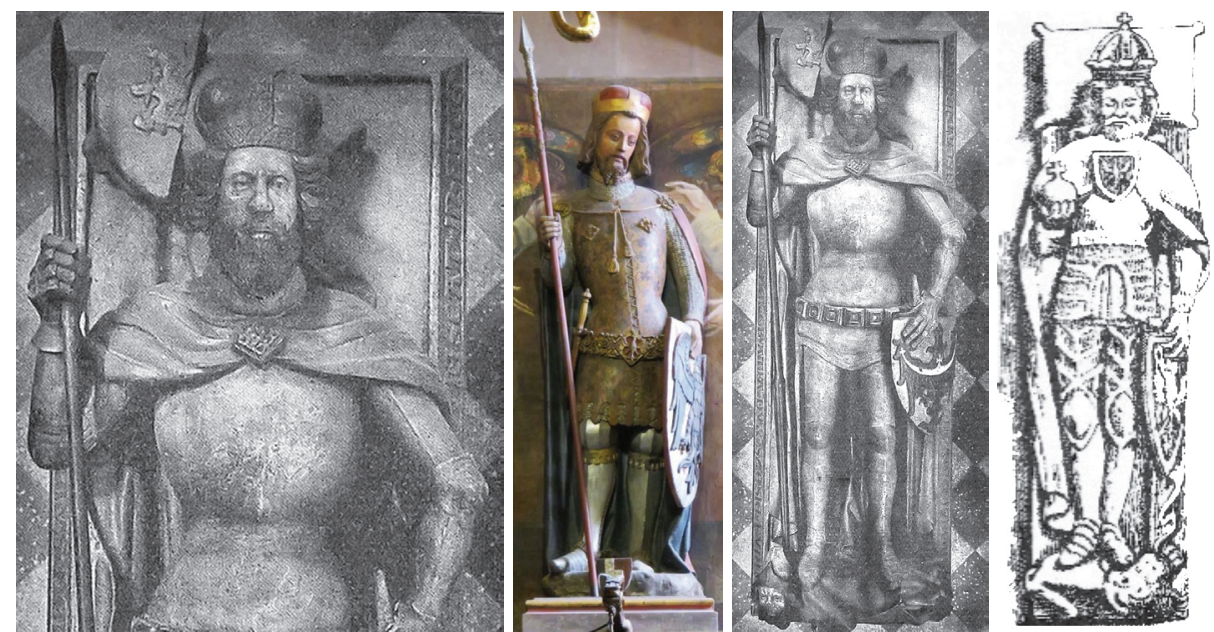

Il. 11, 12, 13 i 14. Porównanie wyglądu postaci króla Bolesława na rycinie A. Myliusa z posągami ks. Henryka Pobożnego (Wrocław) i św. Wacława (Praga)

Niestety, nieliczne nowożytne źródła pisane także dość lakonicznie informują o wyglądzie królewskiego posągu na poznańskim grobowcu Bolesława Chrobrego ${ }^{93}$. Najpełniejszy opis późnego wyglądu postaci króla na katedralnej tumbie przekazał ks. S. Patelski, który w opisie regaliów królewskich wprowadził element zaskakujący i zagadkowy - informację o jednoczesnym dzierżeniu w królewskiej dłoni (prawej?) zarówno miecza, jak i królewskiego jabłka ${ }^{94}$. Informacja ta na trwałe zakorzeniła się

92 Należy cały czas pamiętać, że w uszkodzonym przez czas posągu Henryka Pobożnego „prawa ręka księcia, kopia i miecz - zostały dodane w XIX wieku”. Por. P. Skubiszewski, Nagrobek Henryka II, s. 83.

93 Zestawia je i cytuje Z. Białłowicz-Krygierowa, niestety osłabia ich wymowę, umieszczając opis nie w tekście głównym, lecz w obszernym przypisie 2. Por. tejże, Gotycki grobowiec Bolestawa, s. 71 .

94 W oryginale łacińskim fragment dotyczący postaci królewskiej brzmi: In Summitate Effigies Boleslai Regis in armis cum Paludamento jacentis et in una manu Aquilam Albam tenentis, in altra Gladium cum Pomo Regali, in Capite Coronam de lapide albo [podkr. A.M.]. Zapis, że król w prawej ręce dzierżył gladium cum pomo regali, zdaje się sugerować, iż miecz (lub ew. 
w literaturze - kilkanaście lat temu odwołał się do niej Marek Walczak w cytacie z analitycznej pracy Z. Białłowicz: „na płycie wierzchniej wyobrażona była leżąca na wznak postać króla w płaszczu, zbroi i w koronie, z jabłkiem królewskim i mieczem w jednej, a godłem Orła Białego w drugiej ręce [podkr. A.M.]”' ${ }^{\prime 2}$. A przecież już K. Stronczyński zwrócił uwagę na to, że w tym „opisie widoczna zachodzić musi pomyłka, jest bowiem niepodobieństwem, aby rzeźbiarz w jednej i tej samej ręce mógł zamieścić oba powyższe dostojności monarszej znamiona" ${ }^{\text {" }}$. Tym bardziej że ten zastanawiający opis kłóci się z osiemnastowieczną ikonografią, która w prawej ręce króla Bolesława pokazuje jedynie jabłko - natomiast miecz (drugi?) znajduje się przy lewym boku królewskiego posągu. Aby tę zagadkę nieco rozświetlić, spróbuję przybliżyć okoliczności powstania tego zagadkowego opisu. Trzeba przypomnieć, że pochodzący z Małopolski ks. S. Patelski zdobył wykształcenie na Uniwersytecie Jagiellońskim, gdzie prowadził zajęcia jako „docent extraneus”. Do Poznania przybył w połowie 1746 r. i przez trzy lata ${ }^{97}$ wykładał w Akademii Lubrańskiego. Leży ona tak blisko katedry poznańskiej, że przez ten okres mógł stan i wnętrze tumu dobrze poznać z codziennych odwiedzin. Co więc sprawiło, że tak nieporadnie opisał wygląd regaliów wyobrażonych w prawej ręce królewskiego posągu (łącznie miecz i jabłko)? Zwłaszcza że jednocześnie szczegółowo zrelacjonował pełen zestaw rzeźb zdobiących boki królewskiej tumby. Próbując wyjaśnić tę zagadkę, musimy odwołać się do faktu, że w chwili wyjazdu Patelskiego z Poznania (lato 1749 r.), gmach katedry był w bardzo złym stanie i wkrótce została ona zamknięta dla wiernych z powodu groźby zawalenia (po $28 \mathrm{IV} 1755 \mathrm{r}$.) ${ }^{98}$. Gdy po dziesięcioletnim pobycie w Krakowie, latem 1761 r., wrócił na ponad rok do Poznania ${ }^{99}$, w roku następnym nastąpiło uroczyste otwarcie odremontowanej katedry poznańskiej (30 VI 1762 r.).

berło) mógł być wyposażony w ozdobę przypominającą królewskie jabłko. Cyt. za: Z. Białłowicz-Krygierowa, Gotycki grobowiec Bolestawa, s. 71.

95 Por. M. Walczak, Rzeźba architektoniczna w Matopolsce, s. 378. Fragment ten ma charakter niemal kanoniczny - w taki sposób (za relacją Patelskiego) opisał ksztalt nagrobka już Gumowski w 1926 r. Por. M. Gumowski, Sarkofag grobowy Bolestawa Chrobrego, s. 94.

96 Por. K. Stronczyński, Dawny grobowiec, s. 410/16.

97 W okresie od 8 VIII 1746 do lata 1749 r. zajmowal „stanowisko profesora gramatyki i poezji”. Por. https://www.ipsb.nma.gov.p1/a/biografia/stanislaw-michal-patelski [dostęp 2 VII 2020]. 98 J. Nowacki, Dzieje archidiecezji poznańskiej. T. I. Kościót katedralny w Poznaniu. Studium historyczne, Poznań 1959, s. 144.

99 Byl tu przez ponad rok prefektem seminarium (14 VII 1761 do 28 II 1763). Por. J. Wiesiołowski, Krakowscy profesorowie Akademii Lubrańskiego. Materiały, Kronika Miasta Poznania (1999), nr 2, s. 321. 
To właśnie z tej okazji Patelski wydał Memoriale epitaphiorum, inscriptionum et aliorum scitu dignorum (druk ukazał się w Poznaniu w lipcu 1762 r.), w którym zamieścił też interesujący nas opis królewskiego grobowca. W literaturze przedmiotu ugruntowana jest opinia, że swój zapis tekstów epitafiów na pomnikach grobowych Patelski sporządził w roku $1755^{100}$, trzeba jednak pamiętać o tym, że nie było go wtedy w mieście, opuścił bowiem Poznań latem 1549 r., a więc teksty epitafiów musiały być spisane przez niego przed tą datą. Sądzę, że właśnie ta okoliczność - znaczna odległość czasowa między sporządzeniem tekstu (przed 1749 r.) a jego publikacją (w 1762 r.) - może dostarczyć przesłanek do wyjaśnienie zagadki „włożenia” jednocześnie miecza i jabłka do jednej dłoni króla Bolesława.

Przypuszczam bowiem, że autor mógł połączyć w swym opisie dwa zaobserwowane „stany” królewskiego posągu, które umownie można przypisać dwu obserwacjom: pogodził zapamiętany stan z 1749 r. ${ }^{101}$, gdy zapewne postać królewska była okaleczona i w prawej ręce trzymała coś na kształt miecza (lub berła), z zaobserwowanym po latach (w 1761-1762) widokiem plyty zdemontowanego od 1755 r. i remontowanego nagrobka ${ }^{102}$. Jak wiadomo, co najmniej do 1766 r. grobowiec pozostawał w takim fragmentarycznym stanie ${ }^{103}$, jego odnowiony zaś posąg był już w 1762 r. - jak zdaje się poświadczać rycina ks. Przyłuskiego - wyposażony w królewskie jabłko. Niestety, niewiele jest szans na to, by ten mój domysł można było źródłowo zweryfikować. Na zakończenie przypomnę, że prowadzone przez historyków sztuki analizy typu grobowca króla Bolesława ograniczały się z reguły do ogólnych odniesień stylistycznych nakierowanych na inspiracje płynące z kręgu śląskiej rzeźby nagrobkowej. Choć G. Chmarzyński konkretnie wskazuje jedynie na pochodzący z pierwszej połowy XIV w. nagrobek księcia Henryka Probusa ${ }^{104}$, za to

100 Sądzi tak np. J. Nowacki: „na podstawie autopsji z r. 1755”. Por. tegoż, Dzieje archidiecezji, s. 579.

101 Zdaniem J. Nowackiego ks. Patelski „oglądał jeszcze nienaruszony sarkofag Chrobrego i opisał go". Tamże, s. 587.

102 Jak pisze J. Nowacki: „usunięto w r. 1755 grobowiec królewski niewątpliwie celem jego zabezpieczenia”. Tamże.

103 Opis tego stanu w liście z lipca 1766 r. kapituły do biskupa Czartoryskiego: „Zdawna Bolesława Chrobrego zostający nadgrobek przy reparacji kościoła dla niekształtnej staroświeczczyzny zniesiony należałoby za powinność wdzięczności pierwszemu fundatorowi w innym miejscu ozdobniejszy wystawić, w czym czekać będziemy zdania samego JWXMości”. Por. tamże.

104 G. Chmarzyński, Sarkofagi polskie XIV wieku (Bolestawa Chrobrego w Poznaniu, Henryka IV we Wrocławiu i Wtadystawa Łokietka $w$ Krakowie), Sprawozdania PTPN 12 (1938) [1939], s. 93-98; autor sądzi, że inspiracja dla poznańskiego nagrobka plynęła z Krakowa. 
w jego tekście znajduje się cenne dla mnie spostrzeżenie: pomimo że „nie widzi referent możliwości złączenia kamiennej figury Madonny siedzącej ze zbiorów Towarzystwa Przyjaciół Nauk Pozn. w Muzeum Wielkopolskim (brak Dzieciątka?) z dawnym gotyckim sarkofagiem poznańskim (Gumowski)”, to jednak uważa, iż „rzeźba ta jest też późniejsza (ok. 1370-1380) [od daty śmierci, uważanego za jej fundatora króla Kazimierza]"105. Natomiast Adam Soćko w analizie rzeźby przedstawiającej koronację Maryi ( $w$ katalogu wystawy dzieł sztuki ze zbiorów Poznańskiego Towarzystwa Przyjaciół Nauk), stwierdzil, że scenę tę , już w końcu XIX w. uznawano za pozostałość średniowiecznego nagrobka Bolesława Chrobrego" ${ }^{106}$. W katalogowej „metryczce” rzeźba ta jest opisana jako wytwór „warsztatu dolnośląskiego” i datowana na „3. ćw. XIV w.”, w konkluzji zaś Autor uznał, że jest „wielce prawdopodobne, że relief $\mathrm{z}$ wizerunkiem Marii stanowi trzeci zachowany fragment nagrobka Bolesława Chrobrego”. Z oczywistych względów nie czuję się na siłach, by angażować się w te zagadnienia głębiej - moim zdaniem trzeba w dalszej dyskusji na temat poznańskiej królewskiej tumby uwzględnić ten „śląski trop”, przypominając m.in. wnikliwy artykuł P. Skubiszewskiego o nagrobku Henryka Pobożnego (ujętym tu na szerokim tle porównawczym - z Petrem Perleřem jako punktem odniesienia). Oznaczać to musi dopuszczenie możliwości, że królewski grobowiec Bolesława Chrobrego wzniesiony został dopiero wiele lat po śmierci Kazimierza Wielkiego jako końcowe ogniwo łańcucha inspiracji płynącej z Pragi (fundacje Karola IV zrealizowane po 1373 r.), przez Legnicę (nagrobek Henryka Pobożnego, który powstał po 1381 r.) i docierającej do Poznania zapewne po kilku latach ${ }^{107}$. Pierwszym krokiem do zweryfikowania tego pomysłu powinna być oczywiście analiza pochodzenia kamienia zachowanych fragmentów królewskiego nagrobka ${ }^{108}$, pozwalająca rozstrzygnąć kwestię ich przy-

\section{Tamże, s. 97.}

106 Por. A. Soćko, Maria tronująca ze sceny Koronacji, [w:] Ars una species mille. 150 dziet na 150-lecie Muzeum Narodowego w Poznaniu ze zbiorów Poznańskiego Towarzystwa Przyjaciót Nauk, red. D. Suchocka, Poznań 2007, s. 32 (il. 6). M. Gumowski tak argumentuje przynależność tej figury do królewskiej tumby: „razem z figurą Chrystusa należy ją połączyć w grupę, przedstawiającą Ukoronowanie N.P. Marji. Obie postacie [...] Mają podobne korony, podobne aureole i podobnie sfałdowane szaty. Przedewszystkiem ich wymiary $(69 \mathrm{i} 65 \mathrm{~cm})$ odpowiadają najzupełniej sobie, a dodajmy, oba fragmenty są temsamem jeszcze pobielone wapnem. [...] Chrystus wyciąga rękę, aby Matce włożyć koronę na głowę i że szczegół przy Jej koronie, to właśnie koniec Jego ręki”. Por. tegoż, Sarkofag grobowy Bolestawa Chrobrego, s. 96.

107 Należy tu powtórzyć przywołane przed chwilą zdanie G. Chmarzyńskiego, datującego rzeźbę Madonny na ok. 1370-80.

108 Na wzór badań sarkofagu króla Władysława Jagiełły, gdzie wyniki „ekspertyz materiału, 
należności do jednego zespołu rzeźb. Dopiero następnym - zweryfikowanie ich cech stylistycznych i ewentualnych źródeł (i kierunków) inspiracji. Może wtedy będzie można wyjść poza hipotezy i domysły - także w kwestii chronologii powstania „starodawnego" grobowca króla Bolesława.

Dr hab. Aleksander Małecki, prof. UAM

Uniwersytet im. Adama Mickiewicza w Poznaniu

Wydział Historii

Zakład Historii Nowożytnej do XVIII wieku

ul. Uniwersytetu Poznańskiego 7

61-614 Poznań

e-mail: mauecki@amu.edu.pl

Nadesłany 16 IV 2020

Nadesłany po poprawkach recenzyjnych 10 IX 2020

Zaakceptowany 15 IX 2020

\section{Summary}

The article is dedicated to an attempt at reconstructing the early appearance of the tomb of king Bolesław I the Brave in the Poznań cathedral, destroyed in 1790. By referring to the discussion of the tomb's founder and the changes in its shape, the author has focused on K. Stronczyński's theory from 1887 that the chalcography by A. Mylius (1595) consolidated the early portrait of the king's statue. The scholar was of an opinion that king Bolesław's sculpture was modelled by the tomb of duke Henry II the Pious. The original of the portrait was created by Tomasz Treter, an artist born in Poznan who could have captured the state of the king's statue around 1585 (a variant of the portrait was provided by S. Sarnicki in 1594). The author of the article presents T. Treter's series of royal portraits and suggests that Bolesław I the Brave's statue was reminiscent of that of Henry II the Pious and of Petr Perler's statues of the kings of Bohemia (endowed by emperor Charles IV). Research into the remaining two (or three) stone relics of the tomb will indicate the origin of the raw material and the exact time when the royal tomb was built as well as the source of its artistic inspiration.

Translated by: Ewa Dratwa

z którego został wykonany, wskazują na kamieniołomy węgierskie”. M.A. Janicki, Polityczny program ideowy tumby Wtadysława Jagietty a czas jej powstania, Średniowiecze Polskie i Powszechne 7 (11) (2015), s. 96. 